\title{
PENGARUH KONSENTRASI IAA DAN BERBAGAI JENIS MEDIA TUMBUH TERHADAP PERTUMBUHAN TANAMAN SELEDRI (Apium graveolens L.) DENGAN SISTEM BUDIDAYA HIDROPONIK FERTIGASI
}

\author{
Effect of IAA Concentration and Various Types of Media Growing on the Growth of Celery \\ Plants (Apium Graveolens L.) with Fertigation Hydroponic Cultivation System
}

\author{
Amilia Rara Anggraini, Hasan Basri Jumin, Ernita \\ Program Studi Agroteknologi, Fakultas Pertanian Universitas Islam Riau \\ Jl. Khaharuddin Nasution No.113 Pekanbaru. 28284 \\ Telp: 0761-674681; Fax: 0761-674681 \\ [Diterima: Oktober 2017; Disetujui: Desember 2017]
}

\begin{abstract}
The purpose of the study was to determine the effect of IAA concentration and various types of media growing on celery plant growth with a fertilizing hydroponic cultivation system in interaction as well as each of the main influences. The design used in this study is the Design of Divided Plots in the form of Complete Randomized Design consisting of two factors. The first factor is IAA (A) with a concentration of $0,1,10,100 \mathrm{ppm}$ while the second factor is Various Types of Growing Media (M), namely Cocopeat, Husk Charcoal, Sawdust Powder, Hydroton. The parameters observed were plant height $(\mathrm{cm})$, economical wet weight $(\mathrm{g})$, root volume $(\mathrm{cm} 3)$, average net assimilation rate $(\mathrm{g} / \mathrm{cm} 2 /$ day), average relative growth rate (g/day), number of tillers (fruit), root canopy ratio $(\mathrm{g})$. The last observation data were analyzed statistically and continued with a BNJ follow-up test at the level of 5\%. The results showed that the interaction of IAA concentrations and various types of media grew significantly on the parameters of the plant's wet weight, root volume, and root canopy ratio. The best treatment was found in a combination of treatment of $1.0 \mathrm{ppm}$ IAA concentration and cocopeat growing media. The main effect of IAA concentration was real on all observed parameters. The best treatment is $1.0 \mathrm{ppm}$ IAA concentration. The main influence of various types of media grows significantly for all observational parameters. The best treatment is the cocopeat media.
\end{abstract}

Keywords: IAA, Celery, Hydroponics

ABSTRAK

Tujuan penelitian untuk mengetahui Pengaruh Konsentrasi IAA dan Berbagai Jenis Media Tumbuh Terhadap Pertumbuhan Tanaman Seledri Dengan Sistem Budidaya Hidroponik Fertigasi secara interaksi maupun masing-masing pengaruh utama.Rancangan yang digunakan dalam penelitian ini adalah Rancangan Petak Terbagi dalam bentuk Rancangan Acak Lengkap yang terdiri dari dua faktor. Faktor pertama adalah IAA (A) dengan konsentrasi 0, 1, 10, 100 ppm sedangkan faktor kedua yaitu Berbagai Jenis Media Tumbuh (M) yaitu Cocopeat, Arang Sekam, Serbuk Gergaji, Hydroton. Parameter yang diamati adalah tinggi tanaman $(\mathrm{cm})$, berat basah ekonomis $(\mathrm{g})$, volume akar $\left(\mathrm{cm}^{3}\right)$, rata-rata laju asimilasi bersih $\left(\mathrm{g} / \mathrm{cm}^{2} /\right.$ hari), rata-rata laju pertumbuhan relatif $(\mathrm{g} / \mathrm{hari})$, jumlah anakan (buah), rasio tajuk akar (g). Data pengamatan terakhir dianalisis secara statistik dan dilanjutkan dengan uji lanjut BNJ pada taraf 5\%.Hasil penelitian menunjukkan bahwa secara interaksi konsentrasi IAA dan berbagai jenis media tumbuh nyata terhadap parameter berat basah ekonomis tanaman, volume akar dan rasio tajuk akar. Perlakuan terbaik terdapat pada kombinasi perlakuan konsentrasi IAA 1,0 ppm dan media tumbuh cocopeat. Pengaruh utama konsentrasi IAA nyata terhadap semua parameter pengamatan. Perlakuan terbaik adalah konsentrasi IAA 1,0 ppm. Pengaruh utama berbagai jenis media tumbuh nyata terhadap semua parameter pengamatan.Perlakuan terbaik adalah media cocopeat.

Kata kunci:IAA, Seledri, Hidroponik 


\section{PENDAHULUAN}

Seledri (Apium graveolens L.) adalah tanaman sayuran bumbu berbentuk rumput yang berasal dari benua Amerika, seledri dapat tumbuh pada dataran rendah sampai tinggi dan optimal pada ketinggian tempat 1.000-1.200 m diatas permukaan laut.Tanaman seledri juga dapat dikembangkan pada daerah tropis seperti di Indonesia.

Seledri termasuk salah satu sayuran komersial yang bisa memberikan tambahan pendapatan.Pemanfaatan secara umum sebagai sayuran, daun, tangkai daun, dan umbi sebagai campuran sup.Daun juga dipakai sebagai lalap, atau dipotong kecil-kecil lalu ditaburkan di atas makanan sebagai pelengkap masakan.Seledri (terutama buahnya) sebagai bahan obat sebagai "penyejuk perut".Seledri disebut-sebut sebagai sayuran anti-hipertensi.Fungsi lainnya adalah sebagai peluruh (diuretika), anti reumatik serta pembangkit nafsu makan (karminativa).Umbinya memliki khasiat yang mirip dengan daun tetapi digunakan pula sebagai afrodisiaka (pembangkit gairah seksual).

Seledri mempunyai banyak kandungan gizi antara lain, (per $100 \mathrm{gr}$ ): a. kalori sebanyak 20 kalori, b. protein 1 gram c. lemak 0,1 gram d. hidrat arang 4,6 gram e. kalsium $50 \mathrm{mg}$ f. fosfor $40 \mathrm{mg} \mathrm{g}$. besi $1 \mathrm{mg} \mathrm{h}$. Vitamin A $130 \mathrm{SI}$ i. Vitamin B1 0,03 mg j. Vitamin C $11 \mathrm{mg}$ dan $63 \%$ bagian dapat dimakan (Anonim, 2011).

Banyaknya manfaat dan kegunaan seledri menyebabkan peluang usaha budidaya sangat berpotensi besar terutama dalam meningkatkan pendapatan dan memenuhi permintaan yang terus meningkat.Namun budidaya seledri di Riau umumnya masihdalam skala kecil yang dilakukan sebagai komoditas pengganti bukan sebagai komoditas utama.

Daerah sejuk merupakan tempat tumbuh yang baik pada sayuran seledri sedangkan pada daerah tidak sejuk tumbuh dengan ukuran kerdil sebab seledri membutuhkan cuaca yang lembab dalam pertumbuhan. Budidaya seledri masih jarang dilakukan di kota Pekanbaru karena kondisi lingkungan yang tidak sesuai dengan pertumbuhannya. Badan Pusat Statistik Pekanbaru (2015) jenis sayuran yang dibudidayakan di Pekanbaru adalah sawi, kubis, kangkung, kacang panjang, bayam dan mentimun. Keadaan ini karena perbedaan lokasi budidaya menyebabkan cara budidaya, kondisi tanah, ketinggian tempat, suhu dan curah hujan yang berbeda terutama pemenuhan kebutuhan hara yang menyebabkan pertumbuhan seledri juga berbeda.

Sebagai solusi permasalahan yang begitu besar di atas, manusia secara kreatif telah mengembangkan berbagai teknologi untuk memproduksi tanaman sayuran, buah, dan tanaman hias tanpa menggunakan tanah dengan jumlah air yang sedikit. Tanaman juga dapat dibudiayakan di dalam lingkungan terkendali, sehingga secara efisien dapat memanfaatkan pupuk yang mahal harganya dan beberapa sumberdaya yang terbatas ketersediannya. Teknologi ini dikenal dengan nama Hidroponik. Pada budidaya tanaman dengan sistem hidroponik, pemberian air dan pupuk memungkinkan dilaksanakan secara bersamaan.Manajemen pemupukan (fertilization) dapat dilaksanakan secara terintegrasi dengan manajemen irigasi (irrigation) yang selanjutnya disebut fertigasi (fertilization and irrigation). Dalam sistem hidroponik, pengelolaan air dan hara difokuskan terhadap cara pemberian yang optimal sesuai dengan kebutuhan tanaman, umur tanaman dan kondisi lingkungan sehingga tercapai hasil yang maksimum.

Zat Pengatur Tumbuh dan Media merupakan faktor yang paling berpengaruh dalam pertumbuhan tanaman seledri yang berkualitas.Zat pengatur tumbuh terdiri dari Auksin, Giberelin, Sitokinin, Ethylene, Abscisic acid yang mempunyai fungsi yang berbeda-beda pada tanaman.

Asam Indol Asetat (IAA) adalah salah satu zat pengatur pertumbuhan yang berperan dalam menaikkan tekanan osmosis, menaikkan permeabilitas sel terhadap air, mengurangi tekanan di dinding sel, meningkatkan sintesis protein, dan pengembangan dinding sel. Auksin dapat merangsang pembentukan dan perpanjangan batang serta daun. Selain itu auksin juga berperan dalam pertumbuhan awal akar, meningkatkan jumlah akar pada stek tanaman dan sering digunakan dalam pembibitan tanaman dengan stek. 
Selain zat pengatur tumbuh, faktor lain yang sangat menentukan pertumbuhan tanaman adalah media tumbuh. Media tumbuh merupakan faktor yang paling penting dalam sistem budidaya hidroponik fertigasi.Fungsi media tanam dalam budidaya secara hidror 269 adalah sebagai tempat tumbuh dan te...p. penyimpanan hara dan air sementara yang diperlukan untuk pertumbuhan tanaman. Media tumbuh yang baik harus memenuhi persyaratan antara lain tidak lekas melapuk, tidak menjadi sumber penyakit, menciptakan aerasi yang baik, mampu menyimpan air dan zat hara secara baik, mudah didapat dalam jumlah yang diinginkan dan harganya relatif murah. Media yang digunakan dalam budidaya hidroponik sebagai pengganti fungsi tanah antaranya pasir, batubatuan, cocopeat, rockwoll, spon, serbuk gergaji dan lain-lain asalkan memiliki fungsi sama dengan tanah meskipun tidak seutuhnya sama.

Berdasarkan uraian diatas, maka penulis telah melakukan penelitian tentang "Pengaruh Konsentrasi IAAdan Berbagai Jenis Media Tumbuh Terhadap Pertumbuhan Tanaman Seledri (Apium graveolens L.) Dengan Sistem Budidaya Hidroponik Fertigasi”.

\section{BAHAN DAN METODE}

Penelitian ini telah dilaksanakan di Rumah Kasa Universitas Islam Riau Kubang Jaya Kecamatan Siak Hulu, Kabupaten Kampar.Penelitian ini dilaksanakan selama tiga bulan dari bulan Juli sampai dengan September2017.

Bahan-bahan yang digunakan dalam penelitian ini adalah benih Seledri, Cocopeat, Sekam Padi, Serbuk Gergaji, Hydroton, Indol Asam Asetat (IAA), Polybag ukuran 20 x 35 $\mathrm{cm}$, Spanduk, Selotip. Sedangkat alat-alat yang digunakan adalah Tray Semai, Ruang Semai, Green House, Mesim Pompa Air, Netpot, pH Meter, EC Meter, Selang Fertigasi, Bak Nutrisi, Cangkul, Timbangan Analitik, Meteran, Gelas Ukur, Emitter, Timer, Kamera dan Alat Tulis.

Rancangan yang digunakan dalam penelitian ini adalah Rancangan Petak Terbagi (RPT) dalam bentuk RAL yang terdiri dari dua faktor.Faktor pertama adalah Konsentrasi IAA (A) sebagai petak utama dan faktor kedua
Berbagai Media Tumbuh (M) sebagai anak petak.

Pemberian IAA terdiri dari 4 taraf perlakuan dan perlakuan Berbagai Media Tumbuh terdiri dari 4 taraf perlakuan, sehingga terdapat 16 kombinasi perlakuan dengan 3 kali ulangan. Dengan demikian penelitian ini terdiri dari 48 plot percobaan. Setiap plot terdiri dari 8 tanaman dan 6 tanaman digunakan sebagai sampel, dimana 4 tanaman digunakan untuk sampel pengamatan LPR dan LAB, sementara 2 tanaman lagi digunakan untuk sampelpengamatan lainnya, sehingga keseluruhan tanaman adalah 384 tanaman.

Data hasil pengamatan dari masingmasing perlakuan dianalisis secara statistik dengan menggunakan analisis sidik ragam (ANOVA).Jika $\mathrm{F}$ hitung yang diperoleh lebih besar dari $\mathrm{F}$ tabel, maka dilakukan uji lanjut Beda Nyata Jujur (BNJ) pada taraf $5 \%$.

\section{HASIL DAN PEMBAHASAN}

\section{Tinggi Tanaman (cm)}

Hasil pengamatan tinggi tanaman seledri setelah dianalisis ragam menunjukkan bahwa pengaruh interaksi konsentrasi IAA dan berbagai jenis media tumbuh tidak nyata.Namun pengaruh utama nyata terhadap tinggi tanaman seledri. Hasil uji Beda Nyata Jujur (BNJ) pada taraf 5\% dapat dilihat pada Tabel 1.

Data pada Tabel 1 menunjukkan bahwa pengaruh utama konsentrasi IAAnyata terhadap tinggi tanaman seledri. Dimana konsentrasi IAA $1,0 \mathrm{ppm}$ (A1) memiliki tinggi tanaman tertinggi yaitu: $34,02 \mathrm{~cm}$ dan tidak berbeda nyata dengan perlakuan A2 yaitu dengan tinggi tanaman $32,57 \mathrm{~cm}$, tetapi berbeda nyata dengan perlakuan A0 (tanpa pemberian IAA) dengan tinggi tanaman terendah yaitu $26,78 \mathrm{~cm}$. Hal ini disebabkan karena IAA mampu meningkatkan pertumbuhan dan perkembangan tanaman.

Aplikasi zat pengatur tumbuh pada tanaman merupakan salah satu usaha untuk memaksimalkan hasil tanaman. Zat pengatur tumbuh yang disintesis di dalam tanaman sendiri disebut fitohormon (hormon tanaman) yaitu senyawa yang mengawali reaksi-reaksi biokimia dalam tanaman sehingga memacu berbagai proses fisiologi dan morfogenesis 
tanaman. Zat Pengatur Tumbuh didefinisikan sebagai senyawa organik bukan nutrisi yang mempunyai aktifitas kerja yang sama dengan hormon tanaman dalam konsentrasi tertentu dapat mendorong, menghambat atau secara kualitatif mengubah pertumbuhan dan perkembangan tanaman (Hartanto, 2007).

Data padaTabel 1 menunjukkan perlakuan berbagai media tumbuh nyata terhadap tinggi tanaman seledri. Dimana media tumbuh cocopeat (M1) memiliki tinggi tanaman tertinggi yaitu: $32,80 \mathrm{~cm}$ dan tidak berbeda nyata dengan media tumbuh arang sekam (M2) tetapi berbeda nyata dengan media tumbuh serbuk gergaji (M3) dengan tinggi tanaman terendah yaitu $28,43 \mathrm{~cm}$. Hal ini disebabkan karena cocopeat dapat mengikat dan menyerap air dengan kuat dan mengandung unsur hara esensial.Pertumbuhan tanaman dalam budidaya tanaman hidroponik selain nutrisi yang memberi pengaruh terhadap pertumbuhan tanaman media tumbuh juga sangat memberi peran penting terhadap serapan hara, air, kelancaran drainase dan aerase sehingga dapat menciptakan pertumbuhan yang optimal.Sedangkan perlakuan terendah terdapat pada media tanaman serbuk gergaji (M3). Hal ini disebabkan karena terjadinya pemadatan antara serbuk satu dengan yang lain sehingga akar tanaman pertumbuhan tanaman akan terganggu.

Tabel 1.Rerata Tinggi Tanaman Seledri padaKonsentrasi IAA dan Berbagai Jenis Media Tumbuh $(\mathrm{cm})$.

\begin{tabular}{|c|c|c|c|c|c|}
\hline \multirow[b]{2}{*}{$\begin{array}{l}\text { Konsentrasi } \\
\text { IAA (ppm) }\end{array}$} & \multicolumn{4}{|c|}{ Berbagai Media Tumbuh (M) } & \multirow[b]{2}{*}{ Rerata } \\
\hline & $\begin{array}{l}\text { Cocopeat } \\
\text { (M1) }\end{array}$ & $\begin{array}{l}\text { Arang Sekam } \\
\text { (M2) }\end{array}$ & $\begin{array}{l}\text { Serbuk Gergaji } \\
\text { (M3) }\end{array}$ & $\begin{array}{l}\text { Hydroton } \\
\text { (M4) }\end{array}$ & \\
\hline 0,0 (A0) & 27,80 & 27,10 & 25,67 & 26,53 & $26,78 \mathrm{c}$ \\
\hline $1,0(\mathrm{~A} 1)$ & 36,67 & 35,77 & 30,53 & 33,10 & $34,02 \mathrm{a}$ \\
\hline $10(\mathrm{~A} 2)$ & 34,87 & 33,93 & 29,10 & 32,37 & $32,57 \mathrm{ab}$ \\
\hline $100(\mathrm{~A} 3)$ & 31,87 & 31,17 & 28,43 & 29,93 & $30,35 \mathrm{~b}$ \\
\hline Rerata & $32,80 \mathrm{a}$ & $31,99 \mathrm{a}$ & $28,43 \mathrm{c}$ & $30,48 \mathrm{~b}$ & \\
\hline
\end{tabular}

Angka-angka pada kolom dan baris yang diikuti oleh huruf kecil yang sama menunjukkan tidak berbeda nyata menurut uji beda nyata $(\mathrm{BNJ})$ pada taraf $5 \%$.

\section{Berat Basah Ekonomis Tanaman (g)}

Hasil pengamatan berat basah ekonomis tanaman seledri setelah dianalisis ragam menunjukkan bahwa interaksi dan pengaruh utama perlakuan konsentrasi IAA dan Berbagai Jenis Media Tumbuh nyata terhadap berat basah ekonomis tanaman.Hasil uji Beda Nyata Jujur (BNJ) pada taraf 5\% dapat dilihat pada Tabel 2.

Tabel 2.Rerata Berat Basah Ekonomis Tanaman Seledri pada Konsentrasi IAA dan Berbagai Jenis Media Tumbuh (g).

\begin{tabular}{lccccc}
\hline \multirow{2}{*}{$\begin{array}{c}\text { Konsentrasi } \\
\text { IAA }(\mathrm{ppm})\end{array}$} & $\begin{array}{c}\text { Cocopeat } \\
(\mathrm{M} 1)\end{array}$ & $\begin{array}{c}\text { Arang Sekam } \\
(\mathrm{M} 2)\end{array}$ & $\begin{array}{c}\text { Serbuk Gergaji } \\
(\mathrm{M} 3)\end{array}$ & $\begin{array}{c}\text { Hydroton } \\
(\mathrm{M} 4)\end{array}$ & \multirow{2}{*}{ Rerata } \\
\hline $0,0(\mathrm{~A} 0)$ & $25,87 \mathrm{l}$ & $19,57 \mathrm{~m}$ & $8,50 \mathrm{o}$ & $13,07 \mathrm{n}$ & $16,75 \mathrm{~d}$ \\
$1,0(\mathrm{~A} 1)$ & $97,60 \mathrm{a}$ & $90,40 \mathrm{~b}$ & $45,97 \mathrm{~h}$ & $75,47 \mathrm{~d}$ & $77,36 \mathrm{a}$ \\
$10(\mathrm{~A} 2)$ & $81,37 \mathrm{c}$ & $75,47 \mathrm{~d}$ & $36,87 \mathrm{j}$ & $64,93 \mathrm{e}$ & $64,66 \mathrm{~b}$ \\
$100(\mathrm{~A} 3)$ & $59,63 \mathrm{f}$ & $53,07 \mathrm{~g}$ & $30,80 \mathrm{k}$ & $40,87 \mathrm{i}$ & $46,09 \mathrm{c}$ \\
\hline Rerata & $66,12 \mathrm{a}$ & $59,63 \mathrm{~b}$ & $30,53 \mathrm{~d}$ & $48,58 \mathrm{c}$ & \\
\hline & $\mathrm{KKA}=3,57 \%$ & $\mathrm{KKM}=2,01 \%$ & $\mathrm{BNJ} \mathrm{A}=2,39 \mathrm{BNJ} \mathrm{M}=1,35$ BNJAM = 3,20 \\
\hline
\end{tabular}

Angka-angka pada kolom dan baris yang diikuti oleh huruf kecil yang sama menunjukkan tidak berbeda nyata menurut uji beda nyata $(\mathrm{BNJ})$ pada taraf $5 \%$.

Data pada Tabel 2 menunjukkan bahwa interaksi konsentrasi IAA dan berbagai jenis media tumbuh nyata terhadap berat basah ekonomis tanaman seledri. Dimana konsentrasi IAA $1,0 \mathrm{ppm}$ dan media tumbuh cocopeat (A1M1) memiliki berat basah ekonomis tertinggi yaitu: $97,60 \mathrm{~g}$ dan berbeda nyata 
dengan perlakuan lainnya. Berat basah ekomonis tanaman terendah terdapat pada perlakuan tanpa pemberian konsentrasi IAA dan media serbuk geraji (A0M3) yaitu 8,50 g.

Tingginya berat basah ekonomis tanaman pada konsentrasi IAA 1,0 ppm dan media tumbuh cocopeat (A1M1) 97,60 g. Hal ini disebabkan karena dapat memenuhi unsur hara nitrogen yang dibutuhkan tanaman seledri, dimana dengan terpenuhinya unsur hara maka menyebabkan dinding sel tanaman seledri lebih sekulen sehingga kadar air menjadi tinggi dan translokasi asimilat berlangsung baik, kondisi tersebut menyebabkan berat seluruh bagian tanaman meningkat dan didukung oleh media tumbuh cocopeat yang dapat menyerap hara dan air dengan sangat baik.

Pemberian ZPT dari luar sistem individu disebut juga dengan hormon eksogen, yaitu dengan memberikan bahan kimia sintetik yang dapat berfungsi dan berperan seperti halnya hormon endogen, sehingga mampu menimbulkan rangsangan dan pengaruh pada tumbuhan seperti layaknya fitohormon alami. Disisi lain zat pengatur tumbuh dapat berfungsi sebagai prekursor, yaitu senyawa yang dapat mendahului laju senyawa lain dalam proses metabolisme, dan merupakan bagian dari proses genetik tumbuhan itu sendiri. Seiring dengan perkembangan ilmu pengetahuan dan teknologi serta kepentingan intensifikasi dalam budidaya di sektor pertanian, maka ZPT banyak digunakan terutama untuk meningkatkan kualitas serta kuantitas hasil produksi (Kurnianti, 2012).

\section{Volume Akar $\left(\mathrm{cm}^{3}\right)$}

Hasil pengamatan volume akar tanaman seledri setelah dianalisis ragam menunjukkan bahwa secara interaksi dan pengaruh utama konsentrasi IAA dan Berbagai Jenis Media Tumbuh nyata terhadap volume akar.Hasil uji Beda Nyata Jujur (BNJ) pada taraf 5\% dapat dilihat pada Tabel 3.

Tabel 3.Rerata Volume Akar Seledri pada Konsentrasi IAA dan Berbagai Jenis Media Tumbuh $\left(\mathrm{cm}^{3}\right)$.

\begin{tabular}{|c|c|c|c|c|c|}
\hline \multirow[b]{2}{*}{$\begin{array}{l}\text { Konsentrasi } \\
\text { IAA (ppm) }\end{array}$} & \multicolumn{4}{|c|}{ Berbagai Media Tumbuh (M) } & \multirow[b]{2}{*}{ Rerata } \\
\hline & $\begin{array}{c}\text { Cocopeat } \\
\text { (M1) }\end{array}$ & $\begin{array}{l}\text { Arang Sekam } \\
\text { (M2) }\end{array}$ & $\begin{array}{c}\text { Serbuk } \\
\text { Gergaji (M3) }\end{array}$ & $\begin{array}{l}\text { Hydroton } \\
\text { (M4) }\end{array}$ & \\
\hline 0,0 (A0) & 7,331 & $6,33 \mathrm{~m}$ & $4,33 \mathrm{o}$ & $5,33 n$ & $5,83 \mathrm{~d}$ \\
\hline 1,0 (A1) & $19,67 \mathrm{a}$ & $18,33 b$ & $11,00 \mathrm{hi}$ & $15,00 \mathrm{de}$ & $16,00 \mathrm{a}$ \\
\hline 10 (A2) & $17,33 \mathrm{c}$ & $16,00 \mathrm{~d}$ & $9,00 \mathrm{jk}$ & 14,00 ef & $14,08 \mathrm{~b}$ \\
\hline $100(\mathrm{~A} 3)$ & $13,00 \mathrm{fg}$ & $12,00 \mathrm{gh}$ & $8,33 \mathrm{k}$ & $10,00 \mathrm{ij}$ & $10,83 \mathrm{c}$ \\
\hline Rerata & $14,33 \mathrm{a}$ & $13,17 \mathrm{~b}$ & $8,17 \mathrm{~d}$ & $11,08 \mathrm{c}$ & \\
\hline
\end{tabular}

Angka-angka pada kolom dan baris yang diikuti oleh huruf kecil yang sama menunjukkan tidak berbeda nyata menurut uji beda nyata (BNJ) pada taraf $5 \%$.

Data pada Tabel 3 menunjukkan bahwa interaksi konsentrasi IAA dan berbagai jenis media tumbuh nyata terhadap volume akar.Pemberian perlakuan konsentrasi IAA 1,0 ppm dan media tumbuh cocopeat (A1M1) menghasilkan volume akar tertinggi yaitu: $19,67 \mathrm{~cm}^{3}$ dan berbeda nyata dengan perlakuan lainnya. Volume akar terendah terdapat pada perlakuan tanpa pemberian konsentrasi IAA dan media tumbuh serguk gergaji (A0M3) yaitu $4,33 \mathrm{~cm}^{3}$ dan berbeda nyata dengan perlakuan lainnya.

Tingginya volume akar pada perlakuan konsentrasi IAA 1,0 ppm dan media tumbuh cocopeat (A1M1) 19,67 $\mathrm{cm}^{3}$. Hal ini disebabkan tanaman mampu menyerap hara dari daun tanaman dan melalui akar sehingga hara yang dibutuhkan tanaman tercukupi dengan baik. Akar tanaman akan bertambah panjang dan jumlahnya apabila unsur hara yang terkandung disekitar akar tanaman tersedia dengan cukup dan hara yang diserap tanaman melalui daun akan mempercepat perkembangan pertumbuhan tanaman termasuk dalam penambahan akar tanaman.

Hal tersebut dikarenakan pada bagian ujung batang mampu membentuk berat segar tunas dan jumlah daun yang lebih banyak. Semakin banyak jumlah daun yang membuka sempurna, maka proses fostosintesis berjalan dengan lancer. Dalam proses fotosintesis 
dibutuhkan banyak air, sehingga akan memicu pertumbuhan akar untuk mencari air. Menurut (Gardner et al., 1991) bahwa akar adalah yang pertama mencari air, N, dan faktor-faktor lainnya. Pertumbuhan yang baik dibagian atas tanaman akan merangsang pertumbuhan dibagian bawah sehingga volume akar membesar dan memperluas jangkauan akar untuk memperoleh makanan lebih banyak untuk memenuhi kebutuhan tanaman.

Media tanam yang memenuhi syarat sesuai jenis tanaman sangat menunjang pertumbuhan dan perkembangan tanaman tersebut.Jenis dan sifat media tanam berperan dalam ketersediaan hara dan air.Perbedaan karakteristik media adalah dalam hal kandungan unsur hara dan daya mengikat air tercermin pada agregat, permeabilitas, porositas, kelembaban dan erasi media (Hardjanti, 2005).

\section{Rata-Rata Laju Asimilasi Bersih (g/cm²/hari)}

Hasil pengamatan rata-rata laju asimilasi bersihtanaman seledri setalah dianalisis ragam menunjukkan bahwa secara interaksi perlakuan konsentrasi IAA dan Berbagai Jenis Media Tumbuh tidak nyata.Namun pengaruh utama nyata terhadap laju asimilasi bersih.Hasil uji Beda Nyata Jujur (BNJ) pada taraf 5\% dapat dilihat pada Tabel 4.

Tabel 4. Rerata Laju Asimilasi Bersih Seledri pada Konsentrasi IAA dan Berbagai Jenis Media Tumbuh $\left(\mathrm{g} / \mathrm{cm}^{2} /\right.$ hari $)$

\begin{tabular}{|c|c|c|c|c|c|c|}
\hline \multirow[b]{2}{*}{ HST } & \multirow{2}{*}{$\begin{array}{l}\text { Konsentrasi } \\
\text { IAA (ppm) }\end{array}$} & \multicolumn{4}{|c|}{ Berbagai Media Tumbuh (M) } & \multirow[b]{2}{*}{ Rerata } \\
\hline & & $\begin{array}{l}\text { Cocopeat } \\
\text { (M1) }\end{array}$ & $\begin{array}{l}\text { Arang Sekam } \\
\text { (M2) }\end{array}$ & $\begin{array}{c}\text { Serbuk } \\
\text { Gergaji (M3) }\end{array}$ & $\begin{array}{l}\text { Hydroton } \\
\text { (M4) }\end{array}$ & \\
\hline \multirow{6}{*}{$20-30$} & $0,0(\mathrm{~A} 0)$ & 0,0006 & 0,0005 & 0,0004 & 0,0005 & $0,0005 \mathrm{c}$ \\
\hline & $1,0(\mathrm{~A} 1)$ & 0,0014 & 0,0013 & 0,0009 & 0,0011 & $0,0012 \mathrm{a}$ \\
\hline & $10(\mathrm{~A} 2)$ & 0,0013 & 0,0012 & 0,0007 & 0,0011 & $0,0011 \mathrm{a}$ \\
\hline & $100(\mathrm{~A} 3)$ & 0,0010 & 0,0009 & 0,0007 & 0,0008 & $0,0009 \mathrm{~b}$ \\
\hline & Rerata & $0,0011 \mathrm{a}$ & $0,0010 \mathrm{a}$ & $0,0007 \mathrm{c}$ & $0,0009 \mathrm{~b}$ & \\
\hline & \multicolumn{6}{|c|}{$\mathrm{KKA}=12,32 \% \mathrm{KKM}=12,18 \% \mathrm{BNJ} \mathrm{A}=0,00014 \mathrm{BNJ} \mathrm{M}=0,00014$} \\
\hline \multirow{6}{*}{$30-40$} & $0,0(\mathrm{~A} 0)$ & 0,0023 & 0,0022 & 0,0021 & 0,0021 & $0,0022 \mathrm{c}$ \\
\hline & $1,0(\mathrm{~A} 1)$ & 0,0032 & 0,0031 & 0,0025 & 0,0028 & $0,0029 \mathrm{a}$ \\
\hline & $10(\mathrm{~A} 2)$ & 0,0030 & 0,0029 & 0,0024 & 0,0027 & $0,0027 \mathrm{a}$ \\
\hline & $100(\mathrm{~A} 3)$ & 0,0027 & 0,0026 & 0,0023 & 0,0025 & $0,0025 \mathrm{~b}$ \\
\hline & Rerata & $0,0028 \mathrm{a}$ & $0,0027 \mathrm{a}$ & $0,0023 \mathrm{c}$ & $0,0025 \mathrm{~b}$ & \\
\hline & \multicolumn{2}{|c|}{$\mathrm{KKA}=5,65 \%$} & $\mathrm{KKM}=5,79 \%$ & $\mathrm{BNJ} A=0,00019$ & $\mathrm{BNJ} \mathrm{M}=0,00020$ & \\
\hline \multirow{6}{*}{$40-50$} & $0,0(\mathrm{~A} 0)$ & 0,0067 & 0,0066 & 0,0064 & 0,0065 & $0,0066 \mathrm{c}$ \\
\hline & $1,0(\mathrm{~A} 1)$ & 0,0080 & 0,0079 & 0,0071 & 0,0075 & $0,0076 \mathrm{a}$ \\
\hline & $10(\mathrm{~A} 2)$ & 0,0078 & 0,0077 & 0,0069 & 0,0074 & $0,0075 \mathrm{a}$ \\
\hline & $100(\mathrm{~A} 3)$ & 0,0073 & 0,0072 & 0,0068 & 0,0070 & $0,0071 \mathrm{~b}$ \\
\hline & Rerata & $0,0075 \mathrm{a}$ & $0,0074 \mathrm{ab}$ & $0,0068 \mathrm{bc}$ & $0,0071 \mathrm{~b}$ & \\
\hline & \multicolumn{2}{|c|}{$\mathrm{KKA}=10,61$} & $\mathrm{KKM}=2,16 \%$ & BNJ $\mathrm{A}=0,0010$ & BNJ $\mathrm{M}=0,00020$ & \\
\hline
\end{tabular}

Angka-angka pada kolom dan baris yang diikuti oleh huruf kecil yang sama menunjukkan tidak berbeda nyata menurut uji beda nyata $(\mathrm{BNJ})$ pada taraf $5 \%$.

Data pada Tabel 4, menunjukkan bahwa pemberian konsentrasi IAA nyata terhadap laju asimilasi bersih tanaman seledri, baik pada pengataman LAB 20-30, 30-40, maupun 40-50. Dimana pada pengatan LAB 20-30 nilai LAB tertingi dihasilkan pada pemberian konsentrasi IAA 1,0 ppm (A1) dengan nilai LAB 0,0012 $\mathrm{g} / \mathrm{cm}^{2} /$ hari, dan tidak berbeda nyata dengan perlakuan A2 tetapi berbeda nyata dengan perlakuan lainnya.
Rata-rata laju asimilasi bersih tertinggi tanaman seledri pada 30-40 dihasilkan oleh pemberian konsentrasi IAA 1,0 ppm (A1) yaitu $0,0029 \mathrm{~g} / \mathrm{cm}^{2} /$ hari, kemudian diikuti oleh pemberian konsentrasi IAA $10.0 \mathrm{ppm}$ (A2) yaitu $0,0027 \mathrm{~g} / \mathrm{cm}^{2} /$ hari, pemberian konsentrasi IAA $100 \mathrm{ppm}$ (A3) yaitu $0,0025 \mathrm{~g} / \mathrm{cm}^{2} /$ hari dan nilai LAB terendah dihasilkan tanpa pemberian konsentrasi IAA (A0) yaitu $0,0022 \mathrm{~g} / \mathrm{cm}^{2} /$ hari. Dimana perlakuan A1 tidak berbeda nyata denan perlakuan $\mathrm{A} 2$, perlakuan $\mathrm{A} 0$ berbeda 
nyata dengan perlakuan lainnya.Begitu juga laju asimilasi bersih tanaman seledri tertinggi pada 40-50 dihasilkan pada pemberian konsentrasi IAA $1,0 \mathrm{ppm}$ (A1) yaitu $0,0076 \mathrm{~g} / \mathrm{cm}^{2} / \mathrm{hari}$ kemudian diikuti oleh pemberian konsentrasi IAA $10,0 \mathrm{ppm}(\mathrm{A} 2)$ yaitu $0,0075 \mathrm{~g} / \mathrm{cm}^{2} / \mathrm{hari}$, pemberian konsentrasi IAA 100 ppm (A3) yaitu $0,0071 \mathrm{~g} / \mathrm{cm}^{2} /$ hari dan LAB terendah dihasilkan oleh tanpa pemberian konsentrasi IAA (A0) yaitu $0,0066 \mathrm{~g} / \mathrm{cm}^{2} /$ hari. Dimana perlakuan A1 tidak berbeda nyata dengan perlakuan $\mathrm{A} 2$ tetapi berbeda nyata dengan perlakuan lainnya.Lebih baiknya nilai laju asimilasi bersih tanaman seledri melalui pemberian konsentrasi IAA 1,0 ppm, hal ini disebabkan karena pada taraf tersebut merupakan taraf perlakuan yang terbaik sehingga dapat memberikan pengaruh yang baik terhadap perbaikan kondisi media sehingga dapat memberikan pengaruh yang baik terhadap pertumbuhan tanaman seledri.

Daun merupakan organ utama tempat berlangsungnya fotosintesis. Kedudukan batang seledri pada proses utamanya menyebar secara merata. Oleh karena itu, jumlah daun yan optimum memungkinkan distribusi (pembagian) cahaya antar daun lebih merata.Distribusi cahaya yang lebih merata antar daun menurangi kejadian saling menaungi antar daun sehingga masing-masing daun dapat bekerja sebagaimana mestinya. Peningkatan intensitas cahaya (hingga tingkat optimum) meningkatkan asimilasi bersih total tanaman sehingga fotosintat yang terbentuk pun meningkat. Pembentukan fotosintat yang tinggi ini mendorong kecepatan pembentukan organ tanaman seperti daun.Faktor internal yang turut mempengaruhi laju fotosintesis daun adalah kandungan klorofil daun. Daun yang memiliki kandungan klorofil tinggi diharapkan lebih efisien dalam menangkap energi cahaya matahari untuk fotosintesis (Lawlor, 1987 dan Gardner,1991).

Pengaruh utama berbagai jenis media tumbuh nyata terhadap rata-rata laju asimilasi bersih tanaman seledri baik pada umur 20-30, 30-40 maupun 40-50 HST, dimana nilai laju asimilasi bersih tertinggi dihasilkan oleh media cocopeat (M1) pada LAB 20-30 dengan nilai LAB $0,0011 \mathrm{mg} / \mathrm{cm}^{2} /$ hari dan tidak berbeda nyata dengan perlakuan M2 (media arang sekam) dan berbeda nyata dengan perlakuan lainnya. Pada LAB 30-40 nilai laju asimilasi bersih tertinggi dihasilkan oleh media cocopeat (M1) dengan nilai $0,0028 \mathrm{mg} / \mathrm{cm}^{2} /$ hari dan tidak berbeda nyata dengan perlakuan media arang sekam (A2) tetapi berbeda nyata dengan perlakuan lainnya. Pada LAB 40-50 nilai laju asimilasi bersih tertinggi dihasilkan oleh media cocopeat (M1) dengan nilai $0,0075 \mathrm{mg} / \mathrm{cm}^{2} /$ hari dan tidak berbeda nyata dengan perlakuan media arang sekam (M2) tetapi berbeda nyata dengan perlakuan lainnya. Hal ini disebabkan karena daya menyimpan dan mengikat air dengan sangat kuat.

\section{Rata-Rata Laju Pertumbuhan Relatif (g/hari)}

Hasil pengamatan rata-rata laju pertumbuhan relatif tanaman seledri setelah dianalisis ragam menunjukkan bahwa pengaruh interaksi perlakuan konsentrasi IAA dan Berbagai Jenis Media Tumbuh tidak nyata.Namun pengaruh utama nyata terhadap laju pertumbuhan relatif.Hasil uji Beda Nyata Jujur (BNJ) pada taraf 5\% dapat dilihat pada Tabel 5.

Data pada Tabel 5, menunjukkan bahwa konsentrasi IAA nyata terhadap pertumbuhan laju pertumbuhan relatif tanaman seledri, baik pada pengamatan LPR 20-30, 30-40 maupun 40-50. Dimana pada pengamatan LPR 20-30 nilai LPR tertinggi dihasilkan pada pemberian konsentrasi IAA 1,0 ppm (A1) dengan nilai LPR 0,0234 g/hari dan tidak berbeda nyata dengan A2 tetapi berbeda nyata dengan perlakuan A0. Laju pertumbuhan relatif tertinggi tanaman seledri pada 30-40 dihasilkan oleh pemberian konsentrasi IAA 1,0 ppm (A1) yaitu $0,0280 \mathrm{~g} /$ hari dan tidak berbeda nyata dengan perlakuan A2 tetapi berbeda nyata dengan perlakuan A0. Laju pertumbuhan relatif tertinggi tanaman seledri pada 40-50 dihasilkan oleh pemberian konsentrasi IAA 1,0 ppm (A1) yaitu $0,0310 \mathrm{~g} / \mathrm{hari}$ dan tidak berbeda nyata dengan perlakuan A2 tetapi berbeda nyata dengan perlakuan lainnya. Hal ini disebabkan karena pemberian konsentrasi IAA yang diaplikasikan merupakan perlakuan yang tepat sehingga dapat memenuhi unsure Nitrogen yang dibutuhkan oleh tanaman seledri, dengan demikian proses fotosintesis dapat berjalan dengan baik yang pada akhirnya bahan asimilat yang dihasilkan akan semakin banyak, yang 
mana asimilat dari hasil fotosintesis tersebut akan ditranslokasikan keseluruh bagian tanaman yang tercermin dalam berat kerign tanaman dan akan mempengaruhi nilai laju pertumbuhan relatif tanaman.

Tabel 5.Rerata Laju Pertumbuhan RelatifSeledri dengan Pemberian IAA dan Berbagai Jenis Media Tumbuh (g/hari).

\begin{tabular}{|c|c|c|c|c|c|c|}
\hline \multirow[b]{2}{*}{ HST } & \multirow[b]{2}{*}{$\begin{array}{l}\text { Konsentrasi } \\
\text { IAA (ppm) }\end{array}$} & \multicolumn{4}{|c|}{ Berbagai Media Tumbuh (M) } & \multirow[b]{2}{*}{ Rerata } \\
\hline & & $\begin{array}{l}\text { Cocopeat } \\
\text { (M1) }\end{array}$ & $\begin{array}{c}\text { Arang } \\
\text { Sekam } \\
\text { (M2) }\end{array}$ & $\begin{array}{c}\text { Serbuk } \\
\text { Gergaji } \\
\text { (M3) }\end{array}$ & $\begin{array}{l}\text { Hydroton } \\
\text { (M4) }\end{array}$ & \\
\hline \multirow{6}{*}{$20-30$} & $0,0(\mathrm{~A} 0)$ & 0,0174 & 0,0169 & 0,0156 & 0,0161 & $0,0165 \mathrm{c}$ \\
\hline & $1,0(\mathrm{~A} 1)$ & 0,0256 & 0,0248 & 0,0202 & 0,0230 & $0,0234 \mathrm{a}$ \\
\hline & $10(\mathrm{~A} 2)$ & 0,0240 & 0,0234 & 0,0189 & 0,0222 & $0,0221 \mathrm{ab}$ \\
\hline & $100(\mathrm{~A} 3)$ & 0,0215 & 0,0209 & 0,0181 & 0,0194 & $0,0200 \mathrm{~b}$ \\
\hline & Rerata & $0,0221 \mathrm{a}$ & $0,0215 \mathrm{a}$ & $0,0182 \mathrm{~b}$ & $0,0202 \mathrm{a}$ & \\
\hline & \multicolumn{6}{|c|}{$\mathrm{KKA}=10,84 \% \quad \mathrm{KKM}=6,95 \%$ BNJ $\mathrm{A}=0,0029 \quad \mathrm{BNJ} \mathrm{M}=0,0019$} \\
\hline \multirow{6}{*}{$30-40$} & $0,0(\mathrm{~A} 0)$ & 0,0221 & 0,0215 & 0,0202 & 0,0207 & $0,0211 \mathrm{c}$ \\
\hline & $1,0(\mathrm{~A} 1)$ & 0,0301 & 0,0294 & 0,0248 & 0,0275 & $0,0280 \mathrm{a}$ \\
\hline & $10(\mathrm{~A} 2)$ & 0,0290 & 0,0282 & 0,0235 & 0,0269 & $0,0269 \mathrm{ab}$ \\
\hline & $100(\mathrm{~A} 3)$ & 0,0260 & 0,0254 & 0,0228 & 0,0241 & $0,0246 \mathrm{~b}$ \\
\hline & Rerata & $0,0268 \mathrm{a}$ & $0,0261 \mathrm{a}$ & $0,0228 \mathrm{c}$ & $0,0248 \mathrm{~b}$ & \\
\hline & \multicolumn{6}{|c|}{$\mathrm{KKA}=8,36 \% \quad \mathrm{KKM}=4,38 \% \quad \mathrm{BNJ} \mathrm{A}=0,0027 \quad \mathrm{BNJ} \mathrm{M}=0,0014$} \\
\hline \multirow{6}{*}{$40-50$} & $0,0(\mathrm{~A} 0)$ & 0,0250 & 0,0245 & 0,0233 & 0,0237 & $0,0241 \mathrm{c}$ \\
\hline & $1,0(\mathrm{~A} 1)$ & 0,0331 & 0,0325 & 0,0280 & 0,0305 & $0,0310 \mathrm{a}$ \\
\hline & $10(\mathrm{~A} 2)$ & 0,0318 & 0,0311 & 0,0265 & 0,0299 & 0,0298 a \\
\hline & $100(\mathrm{~A} 3)$ & 0,0292 & 0,0286 & 0,0258 & 0,0272 & $0,0277 \mathrm{~b}$ \\
\hline & Rerata & $0,0298 \mathrm{a}$ & $0,0292 \mathrm{ab}$ & $0,0259 \mathrm{c}$ & $0,0278 \mathrm{~b}$ & \\
\hline & \multicolumn{6}{|c|}{$\mathrm{KKA}=5.52 \% \quad \mathrm{KKM}=3.80 \% \quad \mathrm{BNJ} \mathrm{A}=0.0020 \quad \mathrm{BNJ} \mathrm{M}=0,0014$} \\
\hline
\end{tabular}

Angka-angka pada kolom dan baris yang diikuti oleh huruf kecil yang sama menunjukkan tidak berbeda nyata menurut uji beda nyata (BNJ) pada taraf $5 \%$.

Data pada Tabel 5 laju pertumbuhan relatif tanaman mengalami peningkatan hal ini dikarenakan tanaman berfotosintesis dengan baik dan menghasilkan fotosintat yang peningkatan produksi biomassa tanaman, dan juga dengan tersediannya unsure nitrogen yang tersedia dapat mendukung pertumbuhan tanaman. Hal ini didukung oleh Jumin (2012), menyatakan bahwa pesatnya pertumbuhan tanaman tidak terlepas dari ketersediaan unsur hara didalam tanah.

Pengukuran laju pertumbuhan tanaman juga dapat dilihat dari biomassa tanaman.Biomassa tanaman adalah masa bagian hidup tanaman. Biomassa tanaman merupakan parameter yang sangat sering digunakan untuk menggambarkan dan mempelajari pertumbuhan tanaman, ini disebabkan atas kenyataan taksiran biomassa (berat) yang relatif mudah diukur dan merupakan integrasi dari hampir semua proses pertumbuhan tanaman. Sehingga, pertumbuhan tanaman dapat diartikan sebagai peningkatan jumlah, ukuran, dan berat kering pada tanaman yang tidak dapat balik

Pengaruh utama berbagai jenis media tumbuh nyata terhadap laju pertumbuhan relatif tanaman seledri baik pada umur 20-30, 30-40 maupun 40-50 HST, dimana nilai laju pertumbuah relatif tertinggi dihasilkan oleh media cocopeat (M1) pada LPR 20-30 de nilai LPR 0,0221 g /hari dan tidak be 275 nyata dengan perlakuan M2 (media arang sekam) dan M4 (media hydroton) tetapi berbeda nyata dengan perlakuan M4 (media serbuk gergaji). Pada LPR 30-40 nilai laju pertumbuhan relatif tertinggi dihasilkan oleh media cocopeat (M1) dengan nilai $0,0268 \mathrm{~g}$ /hari dan tidak berbeda nyata dengan perlakuan media arang sekam (A2) tetapi berbeda nyata dengan perlakuan lainnya. Pada LAB 40-50 nilai laju pertumbuhan relatif tertinggi dihasilkan oleh media cocopeat (M1) dengan nilai $0,0298 \mathrm{~g} /$ hari dan tidak berbeda nyata dengan perlakuan media arang sekam (M2) 
tetapi berbeda nyata dengan perlakuan lainnya. Hal ini disebabkan karena daya menyimpan dan mengikat air serta unsur hara dengan baik, maka terpenuhinya unsur hara yang dibutuhkan tanaman secara optimal sehingga berat tanaman bertambah seiring penambahan jaringan pada tanaman.

Pertumbuhan tanaman tidak akan optimal apabila hara yang dibutuhkan kurang tersedia didalam nutrisi. Oleh karena itu selain dari faktor penunjang perbaikan daya serap tanaman terhadap hara tetapi juga perlunya pemberian media yang sesuai dengan kebutuhan tanaman seledri. Hal ini sesuai dengan Hendayono (2000), menyatakan bahwa unsur hara yang diberikan pada tanaman dalam bentuk yang tersedia dan dosis yang seimbang akan dapat memberikan pertumbuhan yang baik pada tanaman, sedangkan tanaman mengalami kekurangan unsure hara akan nampak gejala pertumbuhan tanaman tidak normal karena terjadinya gangguan pada pembelahan sel dan difisiensi dapat menyebabkan terjadinya sel kerdil pada tanaman.

\section{Jumlah Anakan (buah)}

Hasil pengamatan jumlah anakan tanaman seledri setelah dianalis ragam menunjukkan bahwa secara interaksi perlakuankonsentrasi IAA dan Berbagai Jenis Media Tumbuh tidak nyata. Namun pengaruh utama nyata terhadap jumlah anakan seledri.Hasil uji Beda Nyata Jujur (BNJ) pada taraf 5\% dapat dilihat pada Tabel 6.

Tabel 6.Rerata Jumlah AnakanSeledri dengan Pemberian IAA dan Berbagai Jenis Media Tumbuh (buah).

\begin{tabular}{cccccc}
\hline \multirow{2}{*}{$\begin{array}{c}\text { Konsentrasi } \\
\text { IAA (ppm) }\end{array}$} & $\begin{array}{c}\text { Cocopeat } \\
\text { (M1) }\end{array}$ & $\begin{array}{c}\text { Arang Sekam } \\
\text { (M2) }\end{array}$ & $\begin{array}{c}\text { Serbuk } \\
\text { Gergaji (M3) }\end{array}$ & $\begin{array}{c}\text { Hydroton } \\
\text { (M4) }\end{array}$ & \multirow{2}{*}{ Rerata } \\
\hline $0,0(\mathrm{~A} 0)$ & 2,67 & 2,37 & 1,67 & 2,07 & $2,19 \mathrm{c}$ \\
$1,0(\mathrm{~A} 1)$ & 6,33 & 6,00 & 3,67 & 4,87 & $5,22 \mathrm{a}$ \\
$10(\mathrm{~A} 2)$ & 5,67 & 5,17 & 3,00 & 4,67 & $4,63 \mathrm{a}$ \\
$100(\mathrm{~A} 3)$ & 4,33 & 4,00 & 2,83 & 3,33 & $3,63 \mathrm{~b}$ \\
\hline Rerata & $4,75 \mathrm{a}$ & $4,38 \mathrm{a}$ & $2,79 \mathrm{c}$ & $3,73 \mathrm{~b}$ \\
\hline & KKA $=16,56 \%$ & KKM $=12,51 \%$ & BNJ A $=0,85$ & BNJ M $=0,64$ \\
\hline
\end{tabular}

Angka-angka pada kolom dan baris yang diikuti oleh huruf kecil yang sama menunjukkan tidak berbeda nyata menurut uji beda nyata (BNJ) pada taraf $5 \%$.

Data pada Tabel 6 menunjukkan bahwa konsentrasi IAA nyataterhadap jumlah anakan seledri. Dimana konsentrasi IAA $1.0 \mathrm{ppm}$ memiliki jumlah anakan terbanyak yaitu: 5,22 dan tidak berbeda nyata dengan perlakuan A2 yaitu dengan jumlah anakan 4,63, tetapi berbeda nyata dengan perlakuan A0 (tanpa konsentrasi IAA) jumlah anakan terendah yaitu 2.19 .

Perlakuan terbaik pada petak utama konsentrasi IAA terhadap parameter jumlah anakan member respon baik pada A1 (1,0 ppm). Hal ini disebabkan karena ZPT dapat merangsang pertumbuhan dan perkembangan tanaman lebih baik. Hal ini sesuai dengan pendapat Astuti (2000), mengemukakan bahwa kecepatan pembentukan tunas akan mempengaruhi pemanjangan tunas yang diamati pada periode waktu tertentu. Dari sini akan terlihat pengaruh zat stimulus yang diberikan apakah memberikan pengaruh atau tidak ditentukan oleh ketepatan pemberiannya. Sedangkan pada A0 (tanpa pemberian perlakuan) disebabkan karena tidak adanya pemberian ZPT yang dapat memberikan penambahan unsur hara.Unsur hara memegang peran penting dalam pertumbuhan tanaman.

Pemberian zat pengatur tumbuh pada jumlah yang optimum akan merangsang aktivitas auksin dan pembelahan sel pada jaringan meristematik sehingga berpengaruh terhadap pertumbuhan, pembesaran sel dan diferensiasi sel yang meliputi pembentukan akar. Winten (2009), mengemukakan bahwa zat pengatur tumbuh merupakan sekumpulan senyawa organic bukan hara (nutrient), baik yang terbentuk secara alami maupun dibuat oleh manusia. Peranan ZPT dalam tanaman adalah untuk mengatur proses fisiologis seperti pemanjangan dan pembelahan sel, dan juga 
mengatur pertumbuhan akar. Zat perangsang tumbuh atau hormone tumbuh adalah senyawa organic yang dalam konsentrasi rendah $(<1$ $\mathrm{mm}$ ) mampu mendorong, menghambat atau secara kualitatif merubah pertumbuhan dan perkembangan tanaman.

Data pada Tabel 6 bahwa berbagai jenis media tumbuh nyata terhadap jumlah anakan seledri. Dimana pemberian perlakuan M1 (media tumbuh cocopeat) memiliki jumlah anakan 4,75 dan tidak berbeda nyata dengan perlakuan M2 (media tumbuh arang sekam) yaitu dengan jumlah anakan 4,38. Tetapi berbeda nyata dengan perlakuan M3 (media tumbuh serbuk gergaji) yaitu memiliki jumlah anakan terendah 2,79. Hal ini disebabkan karena media cocopeat menyerap unsur hara dengan baik terutama sifat fisik cocopeat menyebabkan akar dapat berkembang dengan maksimal sehingga dapat menjangkau seluruh bagian media untuk mendapatkan unsur hara yang dibutuhkan tanaman. Unsur yang diserapa digunakan sebagai bahan untuk fotosintesis yang akan menghasilkan fotosintat yang digunakan untuk membentuk anakan yang lebih banyak.Sedangkan perlakuan terendah terdapat pada media serbuk gergaji (M3). Hal ini disebabkan karena serbuk gergaji kurang baik bagi perakaran tanaman karena terjadinya pemadatan antara serbuk gergaji antara satu dengan yang lain menyebabkan akar susah mencari nutrisi yang dialirkan melalui pipet emmiter sehingga pertumbuhan tanaman terganggu.

\section{Rasio Tajuk Akar (g)}

Hasil pengamatan rasio tajuk akar tanaman seledri setelah dianalisis ragam, menunjukkan bahwa secara interaksi dan pengaruh utama konsentrasi IAA dan Berbagai Jenis Media Tumbuh nyata terhadap rasio tajuk akar tanaman seledri. Hasil uji Beda Nyata Jujur (BNJ) pada taraf 5\% dapat dilihat pada Tabel 7.

Tabel 7.Rerata Rasio Tajuk Akar Seledri pada Konsentrasi IAA dan Berbagai Jenis Media Tumbuh (g).

\begin{tabular}{lccccc}
\hline \multirow{2}{*}{$\begin{array}{c}\text { Konsentrasi } \\
\text { IAA }(\mathrm{ppm})\end{array}$} & Cocopeat (M1) & $\begin{array}{c}\text { Arang Sekam } \\
(\mathrm{M} 2)\end{array}$ & $\begin{array}{c}\text { Serbuk } \\
\text { Gergaji (M3) }\end{array}$ & Hydroton (M4) & Rerata \\
\cline { 2 - 5 } & $5,20 \mathrm{kl}$ & $4,00 \mathrm{mn}$ & $2,00 \mathrm{o}$ & $3,07 \mathrm{n}$ & $3,57 \mathrm{~d}$ \\
1,0 (A1) & $18,17 \mathrm{a}$ & $16,87 \mathrm{a}$ & $9,27 \mathrm{gh}$ & $13,20 \mathrm{~cd}$ & $14,38 \mathrm{a}$ \\
10 (A2) & $15,43 \mathrm{~b}$ & $14,10 \mathrm{c}$ & $7,23 \mathrm{ij}$ & $12,13 \mathrm{de}$ & $12,23 \mathrm{~b}$ \\
$100(\mathrm{~A} 3)$ & $11,23 \mathrm{ef}$ & $10,07 \mathrm{fg}$ & $6,03 \mathrm{jk}$ & $8,20 \mathrm{hi}$ & $8,88 \mathrm{c}$ \\
\hline Rerata & $12,51 \mathrm{a}$ & $11,26 \mathrm{~b}$ & $6,13 \mathrm{~d}$ & $9,15 \mathrm{c}$ & \\
\hline & $\mathrm{KKA}=12,33 \%$ & $\mathrm{KKM}=4,35 \% \mathrm{BNJ} \mathrm{A}=1,57 \mathrm{BNJ} \mathrm{M}=0,56 \mathrm{BNJAM}=1,32$
\end{tabular}

Angka-angka pada kolom dan baris yang diikuti oleh huruf kecil yang sama menunjukkan tidak berbeda nyata menurut uji beda nyata (BNJ) pada taraf $5 \%$.

Data pada Tabel 7 menunjukkan bahwa interaksi konsentrasi IAA dan berbagai jenis media tumbuh nyata terhadap rasio tajuk akar. Dimana interaksi perlakuan konsentrasi IAA 1,0 ppm dan media tumbuh cocopeat (A1M1) memiliki rasio tajuk akar tertinggi yaitu: 18.17 $\mathrm{g}$ dan tidak berbeda nyata dengan kombinasi perlakuan A1M2 dan berbeda nyata kombinasi perlakuan A0M3 yaitu 2,00 g dan berbeda nyata dengan perlakuan lainnya.

Fotosintesis yang dilakukan secara optimal akan mampu menghasilkan sumber energi bagi pertumbuhan dan pembentukan fitohormon sebagai stimulus pertumbuhan tanaman dan apabila penambahan hormone tumbuh dilakukan pada konsentrasi rendah saat kondisi fotosintesis tanaman berlangsung dengan baik maka jumlahnya akan tepat didalam tubuh tanaman (Dewi, 2007).

Perlakuan terbaik rasio tajuk akar yaitu konsentrasi IAA $1.0 \mathrm{ppm}$ dan media tumbuh cocopeat (A1M1) 18,17 g. Hal ini disebabkan karena konsentrasi IAA mampu memberikan unsure hara yang baik pada media cocopeat sehingga dapat mendukung dan memacu peningkatan tajuk dan akar sehingga tanaman seledri tumbuh dengan sangat baik.

Karjadi dan Buchory (2008), ketepatan ZPT yang ditambahkan sangat penting dalam organogenesis karena akan terjadi interaksi 
antara ZPT yang digunakan dengan zat-zat endogen yang terdapat dalam jaringan tumbuhan. Penambahan ZPT dalam kisaran dosis tidak tepat akan menyebabkan tidak berlangsungnya interaksi tersebut sehingga pertumbuhan tanaman menjadi lambat bahkan dapat menyebabkan penghambatan

Gembong (2005), menyatakan bahwa morfologi dan fisiologi pertumbuhan akar tanaman pada umumnya sangat dipengaruhi oleh kebutuhan tanaman terhadap unsur hara dan air dalam melakukan proses metabolism tubuhnya. Pertumbuhan panjang akar sangat peka terhadap hal tersebut. Semakin baik agregat media atau tanah maka perakaran akan semakin leluasa tumbuh dan berkembang melalui mekanisme pemanjangan sel menjangkau letak sumber hara dan air tersebut.

Media merupakan tempat tumbuh dan tegaknya tanaman serta tempat bagi pertumbuhan dan perkembangan akar tanaman. Meskipun proses pemanjangan akar lebih dominan dipengaruhi oleh agregat media, ketersediaan hara dan air, namun $\mathrm{pH}$ juga memiliki pengaruh penting dalam memberikan pengaruh terhadap keadaan tersebut (Agrihobi, 2007).

\section{KESIMPULAN DAN SARAN}

\section{KESIMPULAN}

Dari hasil penelitian yang telah dilaksanakan dapat diambil kesimpulan bahwa:

1. Interaksi konsentrasi IAA dan berbagai jenis media tumbuh nyata terhadap berat basah ekonomis, volume akar, dan rasio tajuk akar. Perlakuan terbaik adalah kombinasi perlakuan konsentrasi IAA 1,0 ppm dan media tumbuh cocopeat (A1M1)

2. Pengaruh utama konsentrasi IAA dan berbagai jenis media tumbuh nyata terhadap semua parameter pengataman. Perlakuan terbaik adalah konsentrasi IAA 1,0 ppm (A1)

3. Pengaruh utama berbagai jenis media tumbuh nyata terhadap semua parameter pengataman. Perlakuan terbaik adalah media tumbuh cocopeat (M1).

\section{SARAN}

Berdasarkan hasil penelitian ini, disarankan untuk meningkatkan produksi dengan melakukan pemberian konsentrasi IAA $1,0 \mathrm{ppm}$ dan media tumbuh cocopeat pada tanaman.

\section{DAFTAR PUSTAKA}

Agrihobi, S. 2007. Media Tanam untuk Tanaman Hias. Depok: Penebar Swadaya

Anonim, 2011. Manfaat Seledri (Apium graveolens). Diperoleh dari http://www.obatherbalalami.com.Diakses pada tanggal 8 September 2016.

Astuti, P, 2000, Pengaruh Lama, Pengeratan Bahan Stek dan Konsentrasi Rootone F terhadap Pertumbuhan Stek Kopi Robusta (Coffe Protobiont (2016) Vol. 5 (1) : 1-7 7canephora), Skripsi, Universits, Mulawarman, Samarinda.

Badan Pusat Statistik Kota Pekanbaru, Pekanbaru dalam Angka 2015.

Dewi, IR. 2007. Fotosintesis sebagai Proses Dasar. Universitas Padjajaran, Bandung..

Gardner FP, Pearce RB, and Mitchell RL. 1991. Physiology of Crop Plants. Diterjemahkan oleh H.Susilo. Jakarta. Universitas Indonesia Press.

Gembong, T. 2005. Taksonomi Tumbuhan. Yogyakarta : Gadja Mada University Press.

Hartanto D. 2007.Kontribusi akar tanaman rumput dan bambu terhadap peningkatan kuat geser tanah pada lerengan. Teknik Sipil, 3(1):39- 49

Hardjanti, S., 2005. Pertumbuhan Setek Adenium Melalui Penganginan, Asal Bahan Setek, Penggunaan Pupuk Daun dan Komposisi Media, Jurnal Agrosains. 7 (2):100-112.

Hendaryono, D.P.S. 2000 Pembibitan Anggrek dalam Botol. Yogyakarta: Kanisius.

Karjadi dan Buchory.2007. Pengaruh NAA Dan BAP Terhadap Pertumbuhan Jaringan Meristem Bawang Putih Pada Media B5. J.Hort. 17(3) : 217- 223

Kurnianti. N. 2012. Hormon Tumbuhan Atau Zat Pengatur Tumbuh. http:// www.tanijogonegoro.com/2012/11/horm on-tumbuhan-atau-zpt-zatpengatur 
.html.Diakses pada tanggal 1 November 2017.

Lawlor DW. 1987. Photosynthesis: Metabolism, Control and Physiology. John Wiley and Sons, New York.

Winten, I. T. K. 2009.Zat pengatur tumbuh dan peranannya dalam budidaya tanaman.Majalah ilmiah fakultas Pertanian. Universitas Tabanan, vol 6. 49-58 hal. 